\title{
Epigenetic Modifications: Genetic Basis of Environmental Stress Response
}

\author{
Takeo Kubota, Kunio Miyake and Takae Hirasawa \\ Department of Epigenetic Medicine, Faculty of Medicine, University of Yamanashi \\ Japan
}

\section{Introduction}

Genomic DNA is faithfully replicated and divided between two daughter cells in the course of each cell cycle. In order to maintain the inheritance of gene expression patterns, the cell must not only replicate the DNA, but also duplicate its chromatin structure (McNairn \& Gilbert, 2003). Following replication, DNA is methylated and packaged into nucleosomes by the binding of histone octamers to form chromatin. DNA methyltransferases (DNMTs), the enzymes that transfer methyl $\left(\mathrm{CH}_{3}\right)$ residue to $\mathrm{CpG}$ dinulcleotides, are coordinated with DNA replication to maintain the DNA methylation pattern (Fig. 1). DNMTs recognize methylated $\mathrm{CpG}$ dinucleotides on the parent strand and methylate correlating $\mathrm{CpG}$ dinucleotides on the daughter strand (Bestor et al., 1996). This heritability of the DNA methylation pattern, as well as histone modification patterns, is mediated by epigenetic machinery.

Epigenetics was first used by Conrad Waddington in 1939 to describe "the causal interactions between genes and their products, which bring the phenotype into being" (Waddington, 1942). The current definition is "the study of heritable changes in gene expression that occur independent of changes in the primary DNA sequence" (Sharma et al., 2010). Waddington's definition initially referred to the role of the epigenetics in embryonic development, in which cells develop distinct identities despite having the same genetic information; however, the definition of epigenetics has evolved over time as it is implicated in a wide variety of biological processes, including maintenance of the normal gene expression, carcinogenesis and genomic response to environmental stresses.

In this chapter, we take a look at the courent understanding of epigenetic status in human cells, describe human diseases associated with congentital epigenetic errors, and also discuss how human diseases may be caused by acquired epigenetic errors as a result of environmental factors. We also discuss epigenetic therapies that take advantage of the fact that epigenetic changes are resversible.

\section{Epigenetic status in human cells}

The DNA methylation pattern is established during tissue development (Sakashita et al., 2001). Once the pattern is established in a cell, it is stably maintained through DNA replications at each cycle of cell division. Therefore, cells keep distinct identities while containing the same genetic information. 


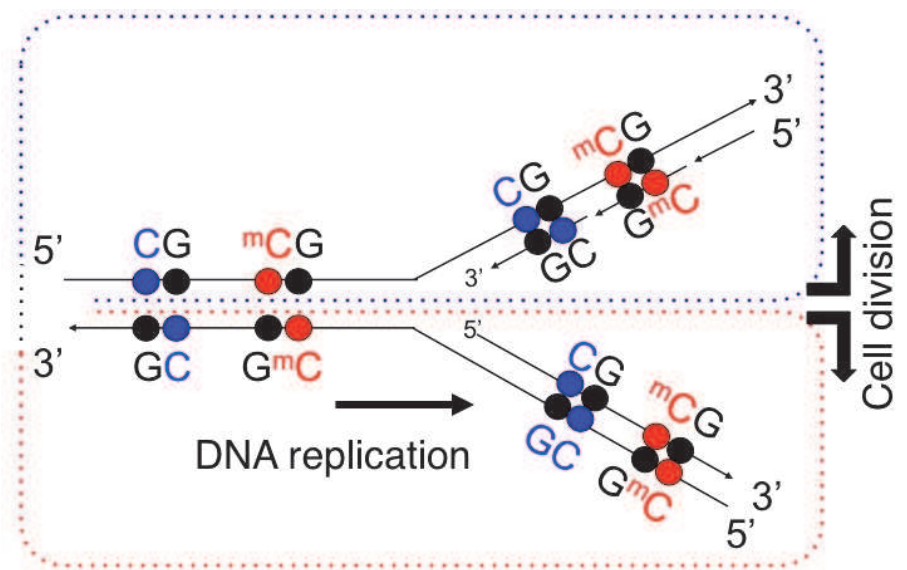

Fig. 1. Maintenance of the DNA methylation pattern during DNA replication and cell division

\subsection{DNA methylation}

During evolution, the CpG dinucleotide, the principal site of DNA methylation, has been selectively depleted through conversion of methylated cytosines to thymidines via a deamination process. Therefore, the human genome has only $10 \%$ of the expected frequency of CpGs, and 70 to $80 \%$ of these are heavily methylated. Small regions of DNA (1 to $2 \%$ ), termed $\mathrm{CpG}$ islands, are not $\mathrm{CpG}$-depleted. $\mathrm{CpG}$ islands are strongly protected from methylation and are associated with the transcription start sites in almost half of human genes. The genome organization facilitated by an epigenetic pattern is only present in higher order eukaryotes including mammals and humans. It is absent in Drosophila, Caenorhabditis elegans, and yeast (Baylin, 1997).

DNA methylation patterns closely correlate with patterns of gene expression (Fig. 2). Heavily methylated genomic regions are generally associated with chromatin organization that is inhibitory to transcription. In humans, such methylated genomic regions often contain highly repeated sequences; methylation may help guard against transcriptional

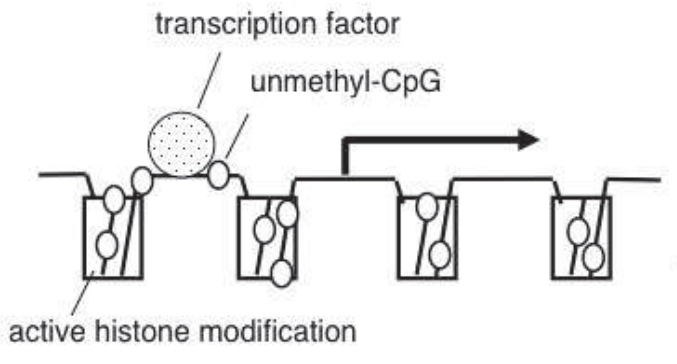

ON state

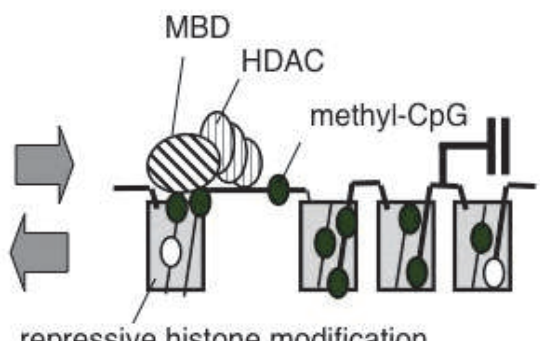

repressive histone modification

\section{OFF state}

Fig. 2. Epigenetic gene regulation via DNA methylation and histone modifications 
expression of parasitic sequences, which were introduced into the genome over evolution by transposable elements and DNA viruses (Bester et al., 1996). In contrast, the unmethylated $\mathrm{CpG}$ islands of genes are associated with chromatin containing highly transcribed DNA.

\subsection{Histone modification}

Histone proteins, which comprise the nucleosomes core, contain a globular C-terminal domain and an unstructured N-terminal tail (Lugar et al., 1997). The N-terminal tails of histones can undergo a variety of posttranslational covalent modifications including acetylation, methylation, phosphorylation, ubiquitylation, and sumoylation (Kouzarides, 2007). The complement of modifications is proposed to store the epigenetic memory inside a cell in the form of a "histone code" that determines the structure and activity of different chromatin regions (Jeniwein et al., 2001) (Fig. 2).

Unlike DNA methylation, histone modifications can lead to either activation or repression depending upon which residues are modified and the type of modifications present. For example, lysine acetylation correlates with transcriptional activation (Kouzarides, 2007; Hebbes et al., 1988), whereas lysine methylation leads to transcriptional activation or repression depending upon which residue is modified and the degree of methylation. For examples, trimethylation of lysine 4 on histone $\mathrm{H} 3$ (H3K4me3) is enriched at transcriptionally active gene promoters (Liang et al., 2004), and trimethylation of lysine 9 on histone $\mathrm{H} 3$ (H3K9me3) and trimethylation of lysine 27 on histone $\mathrm{H} 3$ (H3K27me3) is present at gene promoters that are transcriptionally repressed (Kouzarides, 2007). A vast array of active and repressive histone modifications have been identified, which constitute a complex gene regulatory network essential for the physiological activities of cells (Sharma et al., 2009).

\subsection{Interplay of these epigenetic modifications}

DNA methylation and histone modifications, not only perform individually, but also interact with each other at multiple levels to determine expression status, chromatin organization and cellular identity (Cedar et al., 2009). The two histone modifications (H3K9me3 and H3K27me3) that constitute the silencing mechanism in mammalian cells work in concert with DNA methylation. Furthermore, a histone methyltransferase (HMT) can direct DNA methylation to specific genomic targets by recruiting DNMTs to stably silence genes (Tachibana et al., 2008), and a histone demethylase (HDM) stabilizes DNMT1 protein to maintain DNA methylation (Wang et al., 2009).

DNMTs can in turn recruit methyl-binding domain proteins (MBDs) and histone deacetylases (HDACs) to achieve gene silencing and chromatin condensation (Jones et al., 1998; Nan et al., 1998) (Fig. 2). DNA methylation can also induce histone H3K9 methylation through an MBD (MeCP2), thereby establishing a repressive chromatin state (Fuks et al., 2003).

The interplay of these modifications creates an epigenetic landscape that regulates the way the mammalian genome manifests itself in different cell types, developmental stages and disease states. The distinct patterns of these modifications present in different cellular states serve as a guardian of cellular identity (Sharma et al., 2009).

\subsection{Aberrant epigenetic modifications}

A normal epigenetic landscape is known to be disturbed in specific disease conditions. For example, the cancer epigenome (the whole genomic epigenetic state) is marked by genome- 
wide hypomethylation and site-specific CpG island promoter hypermethylation (Jones \& Baylin, 2002). Global DNA hypomethylation plays a significant role in tumorigenesis and occurs at various genomic sequences including repetitive elements, retrotransposons, CpG poor promoters, introns and gene deserts (Rodriguez et al., 2006). Activation of the retrotransposons due to hypomethylation lead to increased genomic instability by promoting chromosomal rearrangements (Jones et al., 2002; Eden et al., 2003; Howard et al., 2008). Furthermore, methylation is known to stabilize various repetitive sequences. Thus, hypomethylation CAG trinucleotide repeats in a DMNT1-deficient mouse display increased repeat instability (Dion et al., 2008).

In contrast to hypomethylation, which increases genomic instability and activates protooncogenes, region-specific hypermethylation contributes to tumorigenesis by silencing tumor suppressor genes, such as $R b, p 16$ and BRCA1 (Sharma et al., 2009). These genes are involved in cellular processes integral to cancer development and progression, including DNA repair, cell cycle regulation, cell adhesion, apoptosis and angiogenesis. Silencing of DNA repair genes enables cells to accumulate further genetic lesions leading to the rapid progression of cancer. Hypermethylation at the binding site for CCCTC-binding factor (CTCF), a chromatin barrier by preventing the spread of heterochromatin structures, inhibits CTCF binding, and leads to instablity of repetitive sequiences, which is a causingmechanism for varios neurodegenerative diseaases (López Caste et al., 2010). However, how genes are targeted for this aberrant DNA methylation is still unclear.

Both aberrant histone acetylation and histone methylation are found in cancer cells. These changes associated with overexpression of HDACs and dysregulation of HMTs (Halkidou et al., 2004; Song et al., 2005). Alterations in H3K9 and H3K27 methylation patterns are associated with aberrant gene silencing in cancers. It has recently demonstrated that aberrant nucleosome positioning is created by a co-repressor Nerd (nucleosome remodelling and deacetylase) complex that recruits PML-Para (an oncogenenic transcription factor), polycomb repressor complex 2, DNMT3A, and MBD2, resulting in abnormal gene silencing in leukemia (Feng et al 2001; Morey et al., 2008).

Re-establishing normal histone acetylation patterns through treatment with HDAC inhibitors have been shown to have anti-tumorigenic effects, via reactivation of silenced tumor suppressor genes (Carew et al., 2008). Suberoylanilide hydroxamic acid (SAHA), which is an HDAC inhibitor, has now been approved for use in the clinic for treatment of lymphoma (Sharma et al., 2009).

\subsection{Understanding of the global epigenetic landscape}

The global epigenetic landscape that is correlated with important biological processes and disease state has not been comprehensively investigated for most cell types. However, recent advances in genomic technology, in particular high-throughput sequencing, have enabled genome-wide analysis of histone modifications and DNA methylation at nucleotide resolution (Beck, 2010). Large-scale epigenomic mapping studies have the potential to enhance three major areas of science: basic gene regulatory processes, cellular differentiation and reprogramming and the role of epigenetic regulation in disease (Satterlee, 2010). Understanding how the epigenomic state of human embryonic stem (ES) cells changes during the differentiation process is crucial for understanding normal development and establishing epigenomic maps of induced pluriopotent stem (iPS) cells will be essential to enable regenerative medicine to reach its full potential for treating diseases (Deng et al., 2009; Ball et al., 2009; Doi et al., 2009). Genome-wide association studies have been 
successful in identifying genetic variants associated with many different diseases. In the case of diseases that have a strong environmental component, epigenome-wide association studies based on the epigenomic maps of specific cell types that statistically correlate epigenetic variation with phenotypes, could be of great value (Kong et al., 2009).

To generate epigenomic maps for cell types, large-scale epigenomics effort have already been initiated. The NIH Roadmap Epigenomics Program (http://www.roadmapepigenomics.or) will permanently archive data in the GEO database (Http://www.ncbi.nlm.nih.gov/epigenomics) at the US National Center for Biotechnology Information (NCBI), and the International Human Epigenome Consortium (IHEC) (http://ihec-epigenomes.org) aims to expand the number of cell types and generate additional 1,000 reference epigenomes (Beck, 2010) that are not being characterized in the NIH Roadmap Program.

\section{Human diseases associated with congentital epigenetic errors}

Epigenetic gene control is an intrinsic mechanism for normal tissue development and abnormalities in the molecules associated with this mechanism are known to cause various congenital diseases.

\subsection{Genomic imprinting diseases}

Genomic imprinting is the epigenetic phenomenon initially discovered in human diseases. In an imprinted gene, out of the two parental alleles, one allele is active and the other allele is inactive due to epigenetic mechanism such as DNA methylation (Fig. 3C). Therefore, defect in the active allele of the imprinted gene results in the loss of expression. This has been found in neurodevelopmental diseases, Prader-Willi syndrome and Angelman syndrome (Kubota et al., 1997).

\subsection{X-chromosome inactivation disorders}

The $\mathrm{X}$ chromosome has a large number of genes, whereas the $\mathrm{Y}$ chromosome has relatively few genes. Thus, females $(X X)$ have more genes than males $(X Y)$. To minimize this sex imbalance, one of the two $X$ chromosomes in females is inactivated by epigenetic mechanism (Kubota et al., 1998). Improper X inactivation is though to be an embryonic lethal condition. This hypothesis is supported by the recent findings in cloned animals produced by somatic nuclear transfer in which failure of X-chromosome inactivation was observed in the clones with embryonic abortion (Xue et al., 2002; Nolen et al., 2005).Even if one of the $\mathrm{X}$ chromosomes is extremely small due to a large terminal deletion, so that over dosage effect of $X$-linked genes is minimized, the affected female show a severe congenital neurodevelopmental delay(Kubota et al., 2002), indicating that proper gene suppression by epigenetic mechanism is essential for normal development (Fig. 3D).

\subsection{DNA methylation-associated protein diseases}

DNA methylation is a fundamental step in epigenetic gene control, and it is achieved by an addition of the methyl group $\left(\mathrm{CH}_{3}\right)$ to $\mathrm{CpG}$ dinucleotides mediated by DMNTs. Defect in a DNMT (e.g., DNMT3B) can causes an ICF syndrome that is characterized by Immunodeficiency, centromere instability, facial abnormalities, and mild mental retardation (Fig. 3A) (Okano et al, 1999; Shirohzu et al., 2002; Kubota et al., 2004). 
MBDs are also important molecules in the control of gene expression. Mutations in a MBD (e.g., MeCP2) can cause Rett syndrome, which is characterized by seizures, ataxic gait, language dysfunction and autistic behavior (Amir et al, 1999; Chunshu et al., 2006). Therefore, it has been thought that $\mathrm{MeCP} 2$ dysfunction leads to aberrant gene expression in the brain associated with neurological features of the disease. Recent studies have shown that MeCP2 controls a subset of neuronal genes (Chen et al., 2003; Martinowich et al., 2003; Horike et al., 2005; Itoh et al., 2007), suggesting that epigenetic dysregulation of the neuronal genes may cause neurological features of the disease (Fig. 3B).

\section{A. DNMT deficiency}

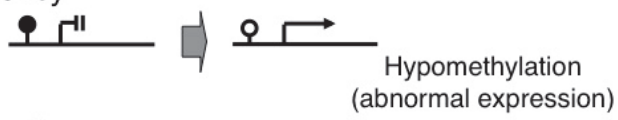

B. MBD abnormality

$$
\text { (abnormal expression) }
$$

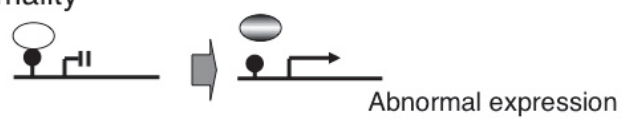

C. Genomic imprinting disorders

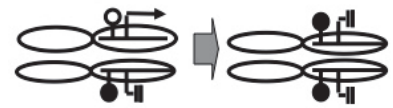

D. X-chromosome inactivation disorders

Abnormal imprinting

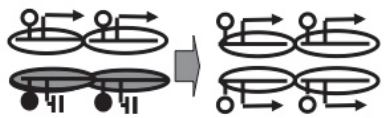

Abnormal activation

Fig. 3. Abnormal epigenetic patterns in human congenital diseases

\section{Proposed human diseases associated with acquired epigenetic errors caused by environmental factors}

Health or diseases is shaped for all individuals by interactions between their genes and the environment. How the environment changes gene expression and how this can lead to a disease are being explored in a fruitful new approach to environmental health research. If these causal relations become clear, they offer new avenues for risk assessment for diseases (Edwards \& Myers, 2007).

\subsection{Social background}

The Ministry of Health, Welfare, and Labor in Japan has recently reported that the number of children with mild neurodevelopmental disorders, such as autism, is increasing by 10,000 cases per year (Basic report, 2005). Similar trends are found in other countries, including the US (Yeargin-Allsopp et al., 2003; Holoden, 2009; Fombonne, 2009), in which the increase is partly attributed to social factors, such as diagnostic substitution in which children formerly diagnosed with mental retardation or learning disabilities are now diagnosed with autism. However, the increase in cases cannot be fully attributed to such diagnostic substitutions, 
and it is possible that biological changes in the brains of the children are also involved in this increase. Thanks to advances in genomic research, several genetic factors for autism have been identified. Mutations in genes encoding synaptic molecules have been identified in a subset of autistic children (Zoghbi, 2003; Persco \& Bourgeron, 2006). However, the increase in autism cannot be solely attributed to genetic factors, because it is unlikely that mutation rates suddenly increased in recent years. Therefore, environmental factors are more likely to be involved in this increase. Epingenetic modifications repreent one mechanism by which enviromental factors can lead to health effects (Qiu, 2006).

\subsection{Acquired neurodevelopmental diseases}

It is known that either a mutation, deletion or a duplication of a specific-neuronal gene causes a neurological disease. In other word, loss-of function, deficiency, or over-dosage can result in the same disease phenotype. For examples, Pelizaeus-Merzbacher disease, a severe child onset disorder, is caused by either a mutation, deletion or a duplication of the PLP1 gene (Inoue et al., 2001), lissencephaly syndrome, a child-onset migration disorder, is caused by either a mutation, deletion or a duplication of LIS1 (Reiner et al., 1993; Bi et al., 2009), Charcot-Marie-Tooth disease, an adult-onset neuromuscular disorder, is caused by either a mutation, deletion or a duplication PMP22 (Roa \& Lupski, 1993), and Perkinson disease is caused by either a mutation, deletion or a duplication the $\alpha$-synuclein gene (Obi et al., 2008). This suggests that the brain is sensitive to the dosage of gene products that requires a strict control system for gene expression. In fact, congenital diseases with defects in epigenetic gene regulation usually show neurological features and mental retardation.

It has recently been reported that short-term mental stress after birth can alter the epigenetic status in the brain, resulting in abnormal behaviour (Weaver et al., 2004). In rats, when the offspring is separated from the mother for a couple of weeks, DNA methylation at the GR (glucocorticoid receptor) gene is increased in the hippocampus in the brain, and this change suppresses gene expression. This study is now considered as an animal model for cuelty in childhoood in human, because hypermethylation of the neuron-specific glucocorticoid receptor promoter, in combination with decreased levels of its expression, have been found in human postmortem hippocampus obtained from suicide victims with a history of childhood abuse (MacGowan et al., 2009), suggesting that adverse effects of early-life stress last life-time long on the DNA methylation programs (Margatroyd et al., 2009). It raise the question of whether neurodevelopmental problem may be the result of epigenetic dysregulation caused by environmental factors in the early life.

\subsection{Environmental factors in fetal period}

Another social issue in Japan is that birth weight has decreased during the past 20 years. This trend is thought to be caused by the popularity of dieting among young women and obsteric physicians' recommendations to minimize pregnacy weight gain in order to reduce the risk of diabetes mellius (Gluckman et al., 2007). Based on current epidemiological studies for famines in the Netherland and China (St Clair et al., 2005; Painter et al., 2006), the generation with lower birth weight is expected to have increased risk for obesity and adult diseases in the future in Japan. This hypothesis is referred to as "Developmental Origin of Health and Diseases (DOHaD)"(Gillman et al., 2007; Silveira et al., 2007). Recent animal expreriments suggest that the developmental basis of adult diseases is due to a change of DNA methylation status of the PPAR $\alpha$ gene, a thrifty gene, in the liver due to malnutrition 
in the fetal period(Lillycrop et al., 2005; Lillycrop et al., 2008) (Fig. 4). Such DNA methylation alterations have been confirmed in individuals who suffered malnutrition during a period of faminine (Tobi et al., 2009).

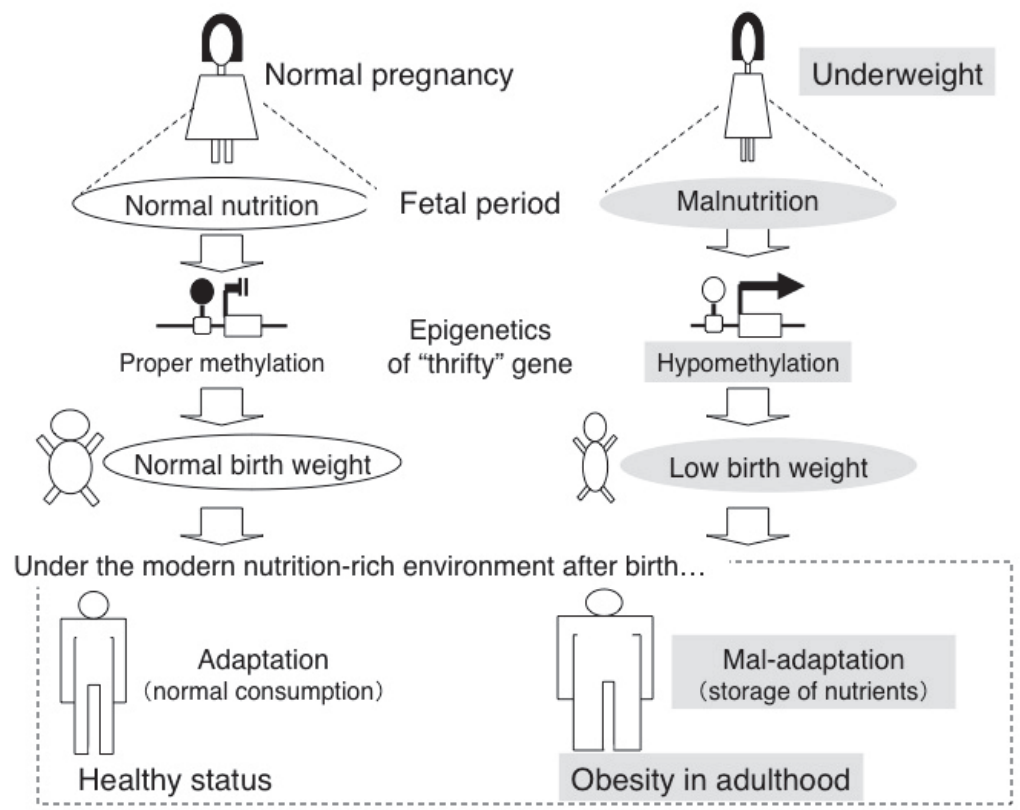

Fig. 4. Epigenetic mechanism proposed in the "Developmental Origin of Health and Diseases" hypothesis

\subsection{Drugs and chemicals affecting epigenetic status}

Drug addiction is an example of mental diseases acquired via epgenetic change. Cocaine and alcohol alter the epigenetic state (chromatin structure) on a subset of neuronal genes, inducing a drug addiction state(Kumar et al., 2005; Pacual et al., 2009). Chemical compounds related to plastics alsopotentially affect the epigenetic status of genes in the brain (Yaoi et al., 2007).

Imipramine, a major antidepressant, in turn has recently been found to retore a depressive state by altering the epigenetics (histone modification) of the $B d n f$ gene in the hippocampus (Tsankova et al., 2006). Valproic acid (VPA), a histone deacetylase (HDAC) inhibitor, is another drug that alters the epigenetic state. VPA normalizes histone acetylation of genes in the hippocampus, which leads to suppression of seizure-induced cognitive impairment by blocking seizure-induced aberrant neurogenesis (Jessbrger et al., 2007). These observations indicate that chemicals that alter epigenetic gene expression, such as HDAC inhibitors, may become candidates for the treatment of neurodevelopmental diseases (Renthal et al., 2008). The findings above are mainly obtained from animal experiments, and there is little evidene from human studies. However, epigenetic differences increase with age in monozygotic twins (Fraga et al., 2005), suggesting that epigenetic status may be altering during aging by environmental factors in humans. 


\section{Epigenetic therapies}

Because epigenetic modifications are a reversible mechanism unlike mutations (substitutions of nucleotides), correction of the epigenetic deffect is potentially easier than correction of the mutations (Fig. 5).

\subsection{DNA methylation donor}

Folic acid is the methyl-donor for transfer to cytosine. Therefore, in order to maintain DNA methylation, sufficient intake of folic acid is essential. Folic acid deficiency during pregnancy is now increasing in Japan. This increases the risk of having babies with neural tube defects (Watanabe et al., 2008). As mentioned above, inappropriate supply of nutrients from mother to the fetus also increases the susceptibility of fetus to develop diabetes mellitus due to epigenetic changes (Park et al., 2008). However, supplementation of folic acid during pregnancy protects the fetus by enriching DNA methylation of the promoter regions of PPAR $\alpha$ and glucocorticoid receptor genes in the liver, leading to suppress gene expression (Buedge et al., 2009). These findings indicate that proper nutrient intakes may alter the phenotype of the offspring through epigenetic changes.

Since 1980s, folic acid has empirically been used for the treatment of autistic children and adults with mental diseases, and several studies have shown that folic acid is effective in a subset of patients (Rimland, 1998; James et al., 2004; Moretti et al., 2005). Although the precise mechanism is not known, it is also possible that folic acid administration may correct the DNA methylation status in genes.

\subsection{Nutrition}

A honey bee secretion known as royal jelly can cause phenotypic change in genetically identical female honeybees to induce the development of a fertile queen. This effect may be mediated by epigenetic changes. A recent study showed that royal jelly removes global DNA methylation, silencing the expression of Dnmt3 during larval development (Kucharski et al., 2008). The phenotypic change from a worker bee to a queen is reproduced by using siRNA that inhibit Dnmt3 (Kucharski et al., 2008). More recently, many kinds of nutrition have been shown to have epigenetic effects and epigenetic therapeutics have been approved by the US Food and drug Administration for treating specific cancers and seizure disorders (Mack, 2006; Sharma et al., 2010).

\subsection{Gene-specific therapy}

Folic acid is relatively safe, since it is a nutrient. However, its effect is global, and it is not specific to a certain gene. It may be better if epigenetic correction is made only to a specific gene that is associated with a disease state. This kind of therapy can be achieved using pyrrole-imidazole (PI) polyamides, small synthetic molecules that recognize and attach to the minor groove of DNA, thereby inhibiting gene transcription by blocking transcription factor binding in a DNA sequence specific manner (Matsuda et al., 2011). Furthermore, PI polyamide conjugated with SAHA, a HDAC inhibitor, can alter the histone modification in a gene-specific manner, resulting in up-regulation of the target gene (Ohtsuki et al., 2010).

\subsection{Exercise and environmental enrichment}

It has recently been discovered that DNA sequence is different in each neuron (Coufal et al., 2009), and that epigenetic change underlies the somatic change (Muotri et al., 2005). This 
phenomenon is based on retrotransposition, in which a repetitive L1 sequence is inserted into various genomic regions when it is hypomethylated, potentially altering expression of adjacent genes. Retrotranposon insertion is activated by deficency of MeCP2 (Muotrri, etal., 2010). Interestingly, the retrotransposition is also activated by voluntary exercise (running) in mice (Muotri et al., 2009), suggesting that exercise may alter the DNA methylation status in neurons.

Studies using a Rett syndrome mouse model that lacks MeCP2 show that environmental enrichment (e.g., availability of stimulating toys) during early postnatal development produces effects on neural development and ameliorates the neurological phenotypes associated with Rett syndrome (Lonetti et al., 2010; Kerr et al., 2010). This suggests that DNA methylation status may be corrected by an apprpriate environment, conpensating for the insuffient MeCP2 function.

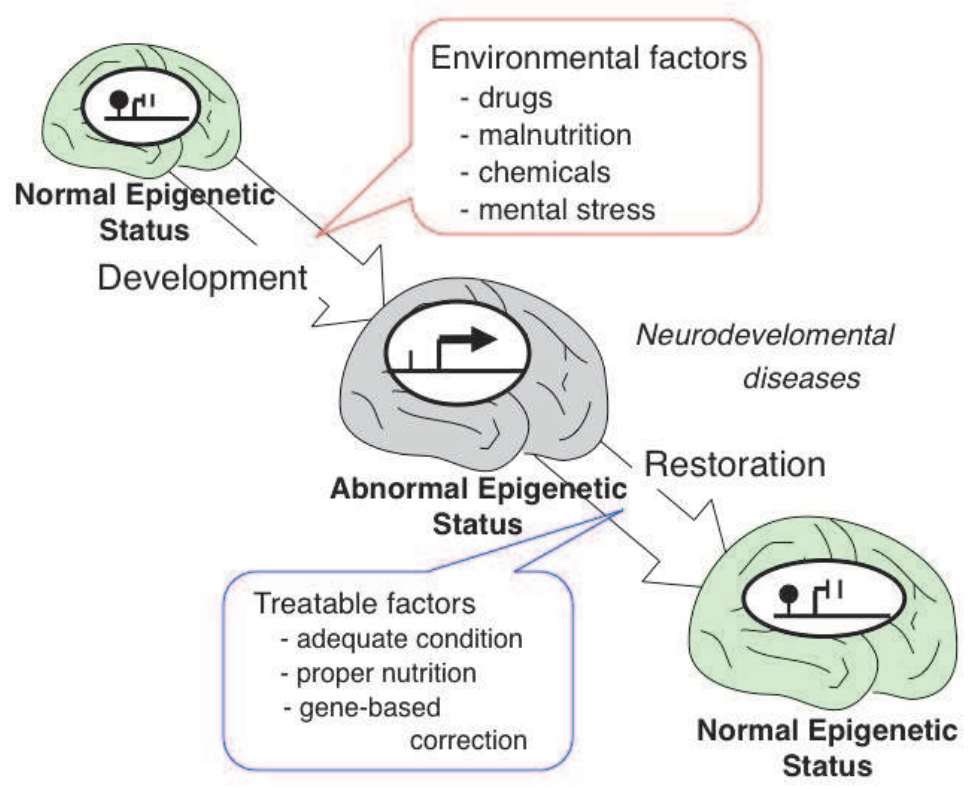

Fig. 5. Overview of epigenetic change and environmental factors in the brain

\section{Conclusion}

Epigenetics is a genetic code, not within the DNA but upon the DNA. Until recently, it has been believed that the epigenetic code is faithfully maintained at the step of DNA replication. However, various environmental factors potentially rewrite the epigenetic codes, which can lead to a disease condition. Moreover, a recent animal study has shown that mental stress not only rewrite the epigenetic code in the brain but also in the gerrmline. Hence, the altered epigenetic code can be transmitted to the next generation, escaping the erasure of epigenetic marks that typically occurs during gametogenesis (Franklin et al., 2010). However, epigenetics is a reversible mechanism, and thus, epigenetic changes are treatable. Therefore, if the transgenerational inheritance of the epigenetic code is true in 
humans and we transmit our own altered epigenetic code to our children, the code can be restored with the offer of appropriate environment and treatment. Although the number and kinds of environmental factors that can alter the epigenetic code are increasing, the precise mechanism is stll largely unknown. Further understanding of how epigenetic modications are changed during DNA replication is warranted in order to elucidate the genetic basis of environmental stress response.

\section{References}

Amir RE, Van den Veyver IB, Wan M, Tran CQ, Francke U, Zoghbi HY. (2001). Rett syndrome is caused by mutations in X-linked MECP2, encoding methyl-CpGbinding protein 2. Nature Genetics, Vol.23, No.2, (October 2001), pp. 185-188, PMID: 10508514

Ball MP, Li JB, Gao Y, Lee JH, LeProust EM, Park IH, Xie B, Daley GQ, Church GM. (2009). Targeted and genome-scale strategies reveal gene-body methylation signatures in human cells. Nature Biotechnology, Vol.27, No.4 (April 2009), pp. 361-368, PMID: 19329998

[Basic investigation report for handicapped children report by Ministry of Health, Welfare, and Labor, Japan.] 2005 (in Japanese).

Baylin SB. (1997). Tying it all together: epigenetics, genetics, cell cycle, and cancer. Science, Vol.277, No.5334, (September 2010), pp. 1948-1949, PMID: 9333948

Beck S. (2010). Taking the measure of the methylome. Nature Biotechnology, Vol.28, No.10 (October 2010), pp. 1026-1028, PMID: 20944589

Bestor T, Laudano A, Mattaliano R, Ingram V. (1988). Cloning and sequencing of a cDNA encoding DNA methyltransferase of mouse cells. The carboxyl-terminal domain of the mammalian enzymes is related to bacterial restriction methyltransferases. Journal of Molecular Biology, Vol.203, No.4, (October 1988), pp. 971-983, PMID: 3210246

Bestor T, Laudano A, Mattaliano R, Ingram V. (1988). Cloning and sequencing of a cDNA encoding DNA methyltransferase of mouse cells. The carboxyl-terminal domain of the mammalian enzymes is related to bacterial restriction methyltransferases. Journal of Molecular Biology, Vol.203, No.4, (October 1988), pp. 971-983, PMID: 3210246

Bi W, Sapir T, Shchelochkov OA, Zhang F, Withers MA, Hunter JV, Levy T, Shinder V, Peiffer DA, Gunderson KL, Nezarati MM, Shotts VA, Amato SS, Savage SK, Harris DJ, Day-Salvatore DL, Horner M, Lu XY, Sahoo T, Yanagawa Y, Beaudet AL, Cheung SW, Martinez S, Lupski JR, Reiner O. (2009). Increased LIS1 expression affects human and mouse brain development. Nature Genetics, Vol.41, No.2, (February 2009), pp.168-177, PMID: 19136950

Burdge GC, Lillycrop KA, Phillips ES, Slater-Jefferies JL, Jackson AA, Hanson MA. Folic acid supplementation during the juvenile-pubertal period in rats modifies the phenotype and epigenotype induced by prenatal nutrition. Journal of Nutrition, Vol.139, No.6 (June 2009), pp. 1054-1060, PMID: 19339705

Carew JS, Giles FJ, Nawrocki ST. Histone deacetylase inhibitors: mechanisms of cell death and promise in combination cancer therapy. Cancer Letters, Vol.269, No.1 (September 2008), pp. 7-17, PMID: 18462867 
Cedar H, Bergman Y. Linking DNA methylation and histone modification: patterns and paradigms. Nature Review Genetics, Vol.10, No.5 (May 2009), pp. 295-304, PMID: 19308066

Chen WG, Chang Q, Lin Y, Meissner A, West AE, Griffith EC, Jaenisch R, Greenberg ME. (2003). Derepression of BDNF transcription inVolves calcium-dependent phosphorylation of MeCP2. Science, Vol.302, No.5646, (October 2003), pp. 885-889, PMID: 14593183

Chunshu Y, Endoh K, Soutome M, Kawamura R, Kubota T. (2006). A patient with classic Rett syndrome with a novel mutation in MECP2 exon 1. Clinical Genetics, Vol.70, No.6, (December 2006), pp. 530-531, PMID: 17101000

Coufal NG, Garcia-Perez JL, Peng GE, Yeo GW, Mu Y, Lovci MT, Morell M, O'Shea KS, Moran JV, Gage FH. (2009). L1 retrotransposition in human neural progenitor cells. Nature, Vol.460, No.7259, (August 2009), pp. 1127-1131, PMID: 19657334

Deng J, Shoemaker R, Xie B, Gore A, LeProust EM, Antosiewicz-Bourget J, Egli D, Maherali N, Park IH, Yu J, Daley GQ, Eggan K, Hochedlinger K, Thomson J, Wang W, Gao Y, Zhang K. (2009). Targeted bisulfite sequencing reveals changes in DNA methylation associated with nuclear reprogramming. Nature Biotechnology, Vol.27, No.4 (April 2009), pp. 353-360, PMID: 19330000

Dion V, Lin Y, Hubert L Jr, Waterland RA, Wilson JH. (2008). Dnmt1 deficiency promotes CAG repeat expansion in the mouse germline. Human Molecular Genetics, Vol.17, No.9, (May 2008), pp. 1306-1317, PMID: 18252747

Doi A, Park IH, Wen B, Murakami P, Aryee MJ, Irizarry R, Herb B, Ladd-Acosta C, Rho J, Loewer S, Miller J, Schlaeger T, Daley GQ, Feinberg AP. (2009). Differential methylation of tissue- and cancer-specific CpG island shores distinguishes human induced pluripotent stem cells, embryonic stem cells and fibroblasts. Nature Genetics, Vol.41, No.12 (December 2009), pp. 1350-1353, PMID: 19881528

Eden A, Gaudet F, Waghmare A, Jaenisch R. (2003). Chromosomal instability and tumors promoted by DNA hypomethylation. Science, Vol.300, No.5618, (April 2003), pp. 455, PMID: 12702868

Edwards TM, Myers JP. (2007). Environmental exposures and gene regulation in disease etiology. Environmental Health Perspectives, Vol.115, No.9, (September 2007), pp. 1264-1270, PMID: 17805414

Feng Q, Zhang Y. (2001). The MeCP1 complex represses transcription through preferential binding, remodeling, and deacetylating methylated nucleosomes. Genes and Development, Vol.15, No.7 (April 2001), pp. 827-832, PMID: 11297506

Fombonne E. (2009). Epidemiology of pervasive developmental disorders. Pediatric Research, Vol.65, No.6, (January 2009), pp. 591-598, PMID: 19218885

Fraga MF, Ballestar E, Paz MF, Ropero S, Setien F, Ballestar ML, Heine-Suñer D, Cigudosa JC, Urioste M, Benitez J, Boix-Chornet M, Sanchez-Aguilera A, Ling C, Carlsson E, Poulsen P, Vaag A, Stephan Z, Spector TD, Wu YZ, Plass C, Esteller M. (2005). Epigenetic differences arise during the lifetime of monozygotic twins. Proceedings of the National Academy Science of the United States of America, Vol.102, No.30, (July 2005), pp. 10604-10609, PMID: 1600993

Franklin TB, Russig H, Weiss IC, Gräff J, Linder N, Michalon A, Vizi S, Mansuy IM. (2010). Epigenetic transmission of the impact of early stress across generations. . Biological Psychiatry, Vol.68, No.5, (April 2010), pp. 408-415, PMID: 20673872 
Fuks F, Hurd PJ, Wolf D, Nan X, Bird AP, Kouzarides T. (2003). The methyl-CpG-binding protein $\mathrm{MeCP} 2$ links DNA methylation to histone methylation. Journal of Biological Chemistry, Vol.278, No.6, (February 2003), pp. 4035-4040, PMID: 12427740

Gillman MW, Barker D, Bier D, Cagampang F, Challis J, Fall C, Godfrey K, Gluckman P, Hanson M, Kuh D, Nathanielsz P, Nestel P, Thornburg KL. (2007). Meeting report on the 3rd International Congress on Developmental Origins of Health and Disease (DOHaD). Pediatric Research, Vol.61, No.5 Pt 1, (May 2007), pp. 625-629, PMID: 17413866

Gluckman PD, Seng CY, Fukuoka H, Beedle AS, Hanson MA. (2007). Low birthweight and subsequent obesity in Japan. Lancet, Vol.369, No.9567, (March 2007), pp. 1081-1082, PMID: 17398304

Halkidou K, Gaughan L, Cook S, Leung HY, Neal DE, Robson CN. (2004). Upregulation and nuclear recruitment of HDAC1 in hormone refractory prostate cancer. Prostate, Vol.59, No.2 (May 2004), pp. 177-189, PMID: 15042618

Hebbes TR, Thorne AW, Crane-Robinson C. (1988). A direct link between core histone acetylation and transcriptionally active chromatin. EMBO Journal, Vol.7, No.5, (May 1988), pp. 1395-1402, PMID: 3409869

Holoden C. (2009). Autism Now. Science, Vol.323, No.5914, (January 2009), pp. 565, DOI: 10.1126/science.323.5914.565c

Horike S, Cai S, Miyano M, Cheng JF, Kohwi-Shigematsu T. (2005). Loss of silent-chromatin looping and impaired imprinting of DLX5 in Rett syndrome. Nature Genetics, Vol.37, No.1, (January 2005), pp. 31-40, PMID: 15608638

Howard G, Eiges R, Gaudet F, Jaenisch R, Eden A. (2008). Activation and transposition of endogenous retroviral elements in hypomethylation induced tumors in mice. Oncogene, Vol.27, No.3 (January 2008), pp. 404-408, PMID: 17621273

Inoue K, Kanai M, Tanabe Y, Kubota T, Kashork CD, Wakui K, Fukushima Y, Lupski JR, Shaffer LG. (2001). Prenatal interphase FISH diagnosis of PLP1 duplication associated with Pelizaeus-Merzbacher disease.Prenatal Diagnosis, Vol.21, No.13, (December 2001), pp. 1133-1136, PMID: 11787038

Itoh M, Ide S, Takashima S, Kudo S, Nomura Y, Segawa M, Kubota T, Mori H, Tanaka S, Horie H, Tanabe Y, Goto Y. (2007). Methyl CpG-binding protein 2 (a mutation of which causes Rett syndrome) directly regulates insulin-like growth factor binding protein 3 in mouse and human brains. Journal of Neuropathology and Experimental Neurology, Vol.66, No.2, (February 2007), pp. 117-123, PMID: 17278996

James SJ, Cutler P, Melnyk S, Jernigan S, Janak L, Gaylor DW, Neubrander JA. (2004). Metabolic biomarkers of increased oxidative stress and impaired methylation capacity in children with autism. American Journal of Clinical Nutrition, Vol.80, No.6 (December 2004), pp. 1611-1617, PMID: 15585776

Jenuwein T, Allis CD. (2001). Translating the histone code. Science, Vol.293, No.5532, (August 2001), pp. 1074-1080, PMID: 11498575

Jessberger S, Nakashima K, Clemenson GD Jr, Mejia E, Mathews E, Ure K, Ogawa S, Sinton $\mathrm{CM}$, Gage FH, Hsieh J. Epigenetic modulation of seizure-induced neurogenesis and cognitive decline. Journal of Neuroscience, Vol.27, No.22 (May 2007), pp. 5967-5975, PMID: 17537967

Jones PA, Baylin SB. (2002). The fundamental role of epigenetic events in cancer. Nature Review Genetics, Vol.3, No.6, (June 2002), pp. 415-428, PMID: 12042769 
Jones PL, Veenstra GJ, Wade PA, Vermaak D, Kass SU, Landsberger N, Strouboulis J, Wolffe AP. (1998). Methylated DNA and MeCP2 recruit histone deacetylase to repress transcription. Nature Genetics, Vol.19, No.2, (June 1998), pp. 187-191, PMID: 9620779

Kerr B, Silva PA, Walz K, Young JI. Unconventional transcriptional response to environmental enrichment in a mouse model of Rett syndrome. Public Library of Science One, Vol.5, No.7, (July 2010), e11534, PMID: 20634955

Kong A, Steinthorsdottir V, Masson G, Thorleifsson G, Sulem P, Besenbacher S, Jonasdottir A, Sigurdsson A, Kristinsson KT, Jonasdottir A, Frigge ML, Gylfason A, Olason PI, Gudjonsson SA, Sverrisson S, Stacey SN, Sigurgeirsson B, Benediktsdottir KR, Sigurdsson $H$, Jonsson $T$, Benediktsson R, Olafsson JH, Johannsson OT, Hreidarsson AB, Sigurdsson G; DIAGRAM Consortium, Ferguson-Smith AC, Gudbjartsson DF, Thorsteinsdottir U, Stefansson K. (2009). Parental origin of sequence variants associated with complex diseases. Nature, Vol.462, No.7275 (December 2009), pp. 868-874, PMID: 20016592

Kouzarides T. (2007). Chromatin modifications and their function. Cell, Vol.128, No.4, (February 2007), pp. 693-705, PMID: 17320507

Kubota T, Das S, Christian SL, Baylin SB, Herman JG, Ledbetter DH. (1997). Methylationspecific PCR simplifies imprinting analysis. Nature Genetics, vo.16, No.1, (May 1997), pp. 16-17, PMID: 9140389

Kubota T, Nonoyama S, Tonoki H, Masuno M, Imaizumi K, Kojima M, Wakui K, Shimadzu M, Fukushima Y. (1998). A new assay for the analysis of X-chromosome inactivation based on methylation-specific PCR. Human Genetics, Vol.104, No.1, (January 1999), pp. 49-55, PMID: 10071192

Kubota T, Wakui K, Nakamura T, Ohashi H, Watanabe Y, Yoshino M, Kida T, Okamoto N, Matsumura M, Muroya K, Ogata T, Goto Y, Fukushima Y. (2002). The proportion of cells with functional $X$ disomy is associated with the severity of mental retardation in mosaic ring $X$ Turner syndrome females. Cytogenetics and Genome Resarch, Vol.99, No.1-4, (2002), pp. 276-284, PMID: 12900575

Kubota T, Furuumi H, Kamoda T, Iwasaki N, Tobita N, Fujiwara N, Goto Y, Matsui A, Sasaki H, Kajii T. (2004). ICF syndrome in a girl with DNA hypomethylation but without detectable DNMT3B mutation. American Journal of Medical Genetics A, Vol.129A, No.1, (September 2004), pp. 290-293, PMID: 15326630

Kucharski R, Maleszka J, Foret S, Maleszka R. (2008). Nutritional control of reproductive status in honeybees via DNA methylation. Science, Vol.319, No.5871 (June 2009), pp. 1827-1830, PMID: 18339900

Kumar A, Choi KH, Renthal W, Tsankova NM, Theobald DE, Truong HT, Russo SJ, Laplant Q, Sasaki TS, Whistler KN, Neve RL, Self DW, Nestler EJ. (2005). Chromatin remodeling is a key mechanism underlying cocaine-induced plasticity in striatum. Neuron, Vol.48, No.2 (October 2005), pp. 303-314, PMID: 16242410

Liang G, Lin JC, Wei V, Yoo C, Cheng JC, Nguyen CT, Weisenberger DJ, Egger G, Takai D, Gonzales FA, Jones PA. (2004). Distinct localization of histone H3 acetylation and H3-K4 methylation to the transcription start sites in the human genome. Proceedings of the National Academy Science of the United States of America, Vol.101, No.19, (May 2004), pp. 7357-7362, PMID: 15123803

Lillycrop KA, Phillips ES, Jackson AA, Hanson MA, Burdge GC. (2005). Dietary protein restriction of pregnant rats induces and folic acid supplementation prevents 
epigenetic modification of hepatic gene expression in the offspring. Journal of Nutrition, Vol.135, No.6 (June 2005), pp. 1382-1386, PMID: 15930441

Lillycrop KA, Phillips ES, Torrens C, Hanson MA, Jackson AA, Burdge GC. (2008). Feeding pregnant rats a protein-restricted diet persistently alters the methylation of specific cytosines in the hepatic PPAR alpha promoter of the offspring. British Journal of Nutrition, Vol.100, No.2, (August 2008), pp. 278-282, PMID: 18186951

Lonetti G, Angelucci A, Morando L, Boggio EM, Giustetto M, Pizzorusso T. (2010). Early environmental enrichment moderates the behavioral and synaptic phenotype of MeCP2 null mice. Biological Psychiatry, Vol.67, No.7, (April 2010), pp. 657-665, PMID: 20172507

López Castel A, Cleary JD, Pearson CE. (2010). Repeat instability as the basis for human diseases and as a potential target for therapy. Nature Reviews Molecular Cell Biology, $l$ Vol.11, No.3, (May 2010), pp. 165-170, PMID: 20177394

Luger K, Mäder AW, Richmond RK, Sargent DF, Richmond TJ. (1997). Crystal structure of the nucleosome core particle at 2.8 A resolution. Nature, Vol.389, No.6648, (January 1997), pp. 251-260, PMID: 9305837

Mack GS. Epigenetic cancer therapy makes headway. Journal of the National Cancer Institute, Vol.98, No.20 (October 2006), pp. 1443-1444, PMID: 17047192

Martinowich K, Hattori D, Wu H, Fouse S, He F, Hu Y, Fan G, Sun YE. (2003). DNA methylation-related chromatin remodeling in activity-dependent BDNF gene regulation. Science, Vol.302, No.5646, (October 2003), pp. 890-893, PMID: 14593184

McGowan PO, Sasaki A, D'Alessio AC, Dymov S, Labonté B, Szyf M, Turecki G, Meaney MJ. (2009). Epigenetic regulation of the glucocorticoid receptor in human brain associates with childhood abuse. Nature Neuroscience, Vol.12, No.3, (December 2009), pp. 342-348, PMID: 19234457

McNairn AJ, Gilbert DM. (2003). Epigenomic replication: linking epigenetics to DNA replication. Bioessays, Vol.25, No.7, (July 2003), pp. 647-656, PMID: 12815720

Matsuda H, Fukuda N, Ueno T, Katakawa M, Wang X, Watanabe T, Matsui S, Aoyama T, Saito K, Bando T, Matsumoto Y, Nagase H, Matsumoto K, Sugiyama H. Transcriptional inhibition of progressive renal disease by gene silencing pyrroleimidazole polyamide targeting of the transforming growth factor- $\beta 1$ promoter. Kidney International, Vol.79, No.1 (January 2011), pp. 46-56, PMID: 20861821

Moretti P, Sahoo T, Hyland K, Bottiglieri T, Peters S, del Gaudio D, Roa B, Curry S, Zhu H, Finnell RH, Neul JL, Ramaekers VT, Blau N, Bacino CA, Miller G, Scaglia F. Cerebral folate deficiency with developmental delay, autism, and response to folinic acid. Neurology, Vol.64, No.6 (March 2005), pp. 1088-1090 PMID: 15781839

Morey L, Brenner C, Fazi F, Villa R, Gutierrez A, Buschbeck M, Nervi C, Minucci S, Fuks F, Di Croce L. MBD3, a component of the NuRD complex, facilitates chromatin alteration and deposition of epigenetic marks. Molecular and Cellular Biology, Vol.28, No.19 (October 2008), pp. 5912-5923, PMID: 18644863

Muotri AR, Chu VT, Marchetto MC, Deng W, Moran JV, Gage FH. (2009). Somatic mosaicism in neuronal precursor cells mediated by L1 retrotransposition. Nature, Vol.435, No.7044, (June 2005), pp. 903-910, PMID: 15959507

Muotri AR, Zhao C, Marchetto MC, Gage FH. (2009). Environmental influence on L1 retrotransposons in the adult hippocampus. Hippocampus, Vol.19, No.10, (November 2009), pp. 1002-1007, PMID: 19771587 
Muotri AR, Marchetto MC, Coufal NG, Oefner R, Yeo G, Nakashima K, Gage FH. (2010). L1 retrotransposition in neurons is modulated by MeCP2. Nature, Vol.468, No.7322, (November 2010), pp. 903-910, PMID: 21085180

Murgatroyd C, Patchev AV, Wu Y, Micale V, Bockmühl Y, Fischer D, Holsboer F, Wotjak CT, Almeida OF, Spengler D. (2009).Dynamic DNA methylation programs persistent adverse effects of early-life stress. Nature Neuroscience, Vol.12, No.12, (December 2009), pp. 1559-1566, PMID: 19898468

Nan X, Ng HH, Johnson CA, Laherty CD, Turner BM, Eisenman RN, Bird A. Transcriptional repression by the methyl-CpG-binding protein MeCP2 inVolves a histone deacetylase complex. Nature, Vol.393, No.6683, (May 1998), pp. 386-389, PMID: 9620804

Nolen LD, Gao S, Han Z, Mann MR, Gie Chung Y, Otte AP, Bartolomei MS, Latham KE. (2005). $X$ chromosome reactivation and regulation in cloned embryos. Developmental Biology, Vol.279, No.2, (March 2005), pp. 525-40, PMID: 15733677

Obi T, Nishioka K, Ross OA, Terada T, Yamazaki K, Sugiura A, Takanashi M, Mizoguchi K, Mori H, Mizuno Y, Hattori N. (2008). Clinicopathologic study of a SNCA gene duplication patient with Parkinson disease and dementia. Neurology, Vol.70, No.3, (January 2008), pp. 238-241, PMID: 18195271

Ohtsuki, M. T. Kimura, M. Minoshima M, Suzuki T, Ikeda M, Bando T, Nagase H, Shinohara K, Sugiyama H. (2009). Synthesis and properties of PI polyamide-SAHA conjugate, Tetrahedron Letters, Vol.50, No.52, (available online October 2009), pp. 7288-7292

Okano M, Bell DW, Haber DA, Li E. (1999). DNA methyltransferases Dnmt3a and Dnmt3b are essential for de novo methylation and mammalian development. Cell, Vol.99, No.3, (October 1999), pp. 276-257, PMID: 10555141

Painter RC, de Rooij SR, Bossuyt PM, Simmers TA, Osmond C, Barker DJ, Bleker OP, Roseboom TJ. Early onset of coronary artery disease after prenatal exposure to the Dutch famine. American Journal of Clinical Nutrition, Vol.84, No.2, (August 2006), pp. 322-327, PMID: 16895878

Park JH, Stoffers DA, Nicholls RD, Simmons RA. (2008). Development of type 2 diabetes following intrauterine growth retardation in rats is associated with progressive epigenetic silencing of Pdx1.Journal of Clinical Investigation, Vol.118, No.6, (June 2008), pp. 2316-2324, PMID: 18464933

Pascual M, Boix J, Felipo V, Guerri C. (2009). Repeated alcohol administration during adolescence causes changes in the mesolimbic dopaminergic and glutamatergic systems and promotes alcohol intake in the adult rat. Jounral of Neurochemistry, Vol.108, No.4, (February 2009), pp. 920-931, PMID: 19077056

Persico AM, Bourgeron T. (2006). Searching for ways out of the autism maze: genetic, epigenetic and environmental clues. Trends in Neurosciences, Vol.29, No.7, (July 2006), pp. 349-358, PMID: 16808981

Qiu J. (2006). Epigenetics: unfinished symphony. Nature, Vol.441, No.7090, (May 2006), pp. 143-145, PMID: 16688142

Reiner O, Carrozzo R, Shen Y, Wehnert M, Faustinella F, Dobyns WB, Caskey CT, Ledbetter DH. (1993). Isolation of a Miller-Dieker lissencephaly gene containing $G$ protein beta-subunit-like repeats. Nature, Vol.364, No.6439, (August 1993), pp. 717-721, PMID: 835578 
Renthal W, Nestler EJ. Epigenetic mechanisms in drug addiction. Trends in Molecular Medicine, Vol.14, No.8, (August 2008), pp. 341-350, PMID: 18635399

Rimland B. Controversies in the treatment of autistic children: vitamin and drug therapy. (1988). Journal of Child Neurology, Vol.3, Suppl (1988), pp. S68-72, PMID: 3058789

Roa BB, Lupski JR. (1993). Molecular basis of Charcot-Marie-Tooth disease type 1A: gene dosage as a novel mechanism for a common autosomal dominant condition. American Journal of the Medical Sciences, Vol.306, No.3, (September 1993), pp. 177184, PMID: 8128981

Rodriguez J, Frigola J, Vendrell E, Risques RA, Fraga MF, Morales C, Moreno V, Esteller M, Capellà G, Ribas M, Peinado MA. (2006). Chromosomal instability correlates with genome-wide DNA demethylation in human primary colorectal cancers. Cancer Research, Vol.66, No.17, (September 2006), pp. 8462-9468, PMID: 16951157

Sakashita K, Koike K, Kinoshita T, Shiohara M, Kamijo T, Taniguchi S, Kubota T. (2001). Dynamic DNA methylation change in the CpG island region of p15 during human myeloid development. Journal of Clinical Investigation, Vol.108, No.8, (October 2001), pp. 1195-1204, PMID: 1160262

Satterlee JS, Schübeler D, Ng HH. (2010). Tackling the epigenome: challenges and opportunities for collaboration. Nature Biotechnology, Vol.28, No.10 (October 2010), pp. 1039-1044, PMID: 20944594

Sharma S, Kelly TK, Jones PA. (2010). Epigenetics in cancer. Carcinogenesis, Vol.31, No.1, (January 2010), pp. 27-36, PMID: 19752007

Shirohzu H, Kubota T, Kumazawa A, Sado T, Chijiwa T, Inagaki K, Suetake I, Tajima S, Wakui K, Miki Y, Hayashi M, Fukushima Y, Sasaki H. (2002). Three novel DNMT3B mutations in Japanese patients with ICF syndrome. American Journal of Medical Genetics,. Vol.112, No.1, (September 2002), pp. 31-37, PMID: 12239717

Silveira PP, Portella AK, Goldani MZ, Barbieri MA. (2007). Developmental origins of health and disease (DOHaD). Jornal de Pediatria, Vol.83, No.6 Pt 1, (November-December 2007), pp. 494-504, PMID: 18074050

Song J, Noh JH, Lee JH, Eun JW, Ahn YM, Kim SY, Lee SH, Park WS, Yoo NJ, Lee JY, Nam SW. (2005). Increased expression of histone deacetylase 2 is found in human gastric cancer. APMIS, Vol.113, No.4(April 2005), pp. 264-268, PMID: 15865607

St Clair D, Xu M, Wang P, Yu Y, Fang Y, Zhang F, Zheng X, Gu N, Feng G, Sham P, He L. (2005). Rates of adult schizophrenia following prenatal exposure to the Chinese famine of 1959-1961. JAMA, Vol.294, No.5, (August 2005), pp. 557-562, PMID: 16077049

Tachibana M, Matsumura Y, Fukuda M, Kimura H, Shinkai Y. (2008). G9a/GLP complexes independently mediate $\mathrm{H} 3 \mathrm{~K} 9$ and DNA methylation to silence transcription. EMBO Journal, Vol.27, No.20, (October 2008), pp. 2681-2690, PMID: 18818694

Tsankova NM, Berton O, Renthal W, Kumar A, Neve RL, Nestler EJ. (2006). Sustained hippocampal chromatin regulation in a mouse model of depression and antidepressant action. Nature Neuroscience, Vol.9, No.4, (April 2006), pp. 519-525, PMID: 16501568

Tobi EW, Lumey LH, Talens RP, Kremer D, Putter H, Stein AD, Slagboom PE, Heijmans BT. DNA methylation differences after exposure to prenatal famine are common and timing- and sex-specific. Human Molecular Genetics, Vol.18, No.21, (November 2009), pp. 4046-4053, PMID: 19656776 
Waddington CH. (1942). Epigenotype. Endeavour, Vol.1, (1942), pp. 18-20.

Wang J, Hevi S, Kurash JK, Lei H, Gay F, Bajko J, Su H, Sun W, Chang H, Xu G, Gaudet F, Li $\mathrm{E}$, Chen T. The lysine demethylase LSD1 (KDM1) is required for maintenance of global DNA methylation. Nature Genetics, Vol.41, No.1 (January 2009), pp. 125-129, PMID: 19098913

Watanabe H, Fukuoka H, Sugiyama T, Nagai Y, Ogasawara K, Yoshiike N. (2008). Dietary folate intake during pregnancy and birth weight in Japan. European Journal of Nutrition, Vol.47, No.6, (September 2008), pp. 341-347, 2008, PMID: 18709472

Weaver IC, Cervoni N, Champagne FA, D'Alessio AC, Sharma S, Seckl JR, Dymov S, Szyf M, Meaney MJ. (2004). Epigenetic programming by maternal behavior. Nature Neuroscience, Vol.7, No.8, (August 2004), pp. 847-854, PMID: 15220929

Xue F, Tian XC, Du F, Kubota C, Taneja M, Dinnyes A, Dai Y, Levine H, Pereira LV, Yang X. (2002). Aberrant patterns of $X$ chromosome inactivation in bovine clones. Nature Genetics, Vol.31, No.2, (Jun 2002), pp. 216-220, PMID: 12032569

Yaoi T, Itoh K, Nakamura K, Ogi H, Fujiwara Y, Fushiki S. (2008). Genome-wide analysis of epigenomic alterations in fetal mouse forebrain after exposure to low doses of bisphenol A. Biochemical and Biophysical Research Communications, Vol.376, No.3, (November 2008), pp. 563-567, PMID: 18804091

Yeargin-Allsopp M, Rice C, Karapurkar T, Doernberg N, Boyle C, Murphy C. (2003). Prevalence of autism in a US metropolitan area. JAMA, Vol.289, No.1, (January2003), pp. 49-55, PMID: 12503976

Zoghbi HY.(2003). Postnatal neurodevelopmental disorders: meeting at the synapse? Science, Vol.302, No.5646, (October 2003), pp. 862-830, PMID: 14593168 


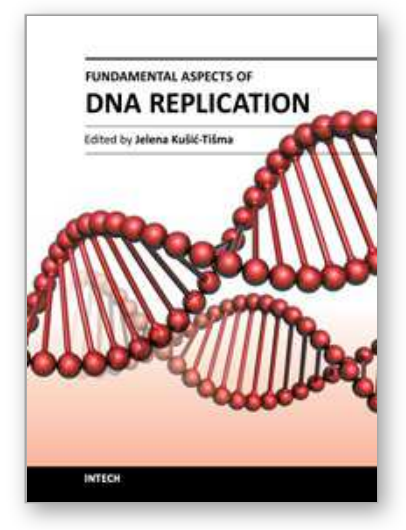

\author{
Fundamental Aspects of DNA Replication \\ Edited by Dr. Jelena Kusic-Tisma
}

ISBN 978-953-307-259-3

Hard cover, 306 pages

Publisher InTech

Published online 26, September, 2011

Published in print edition September, 2011

DNA replication, the process of copying one double stranded DNA molecule to produce two identical copies, is at the heart of cell proliferation. This book highlights new insights into the replication process in eukaryotes, from the assembly of pre-replication complex and features of DNA replication origins, through polymerization mechanisms, to propagation of epigenetic states. It also covers cell cycle control of replication initiation and includes the latest on mechanisms of replication in prokaryotes. The association between genome replication and transcription is also addressed. We hope that readers will find this book interesting, helpful and inspiring.

\title{
How to reference
}

In order to correctly reference this scholarly work, feel free to copy and paste the following:

Takeo Kubota, Kunio Miyake and Takae Hirasawa (2011). Epigenetic Modifications: Genetic Basis of Environmental Stress Response, Fundamental Aspects of DNA Replication, Dr. Jelena Kusic-Tisma (Ed.), ISBN: 978-953-307-259-3, InTech, Available from: http://www.intechopen.com/books/fundamental-aspects-ofdna-replication/epigenetic-modifications-genetic-basis-of-environmental-stress-response

\section{INTECH}

open science | open minds

\section{InTech Europe}

University Campus STeP Ri

Slavka Krautzeka 83/A

51000 Rijeka, Croatia

Phone: +385 (51) 770447

Fax: +385 (51) 686166

www.intechopen.com

\section{InTech China}

Unit 405, Office Block, Hotel Equatorial Shanghai

No.65, Yan An Road (West), Shanghai, 200040, China

中国上海市延安西路65号上海国际贵都大饭店办公楼 405 单元

Phone: +86-21-62489820

Fax: +86-21-62489821 
(C) 2011 The Author(s). Licensee IntechOpen. This chapter is distributed under the terms of the Creative Commons Attribution-NonCommercialShareAlike-3.0 License, which permits use, distribution and reproduction for non-commercial purposes, provided the original is properly cited and derivative works building on this content are distributed under the same license. 